\title{
Documentation of Ancestral Caddo Ceramic Vessels from the Harold Williams Site (41CP10), Camp County, Texas
}

Timothy K. Perttula

Heritage Research Center, Stephen F. Austin State University

Follow this and additional works at: https://scholarworks.sfasu.edu/ita

Part of the American Material Culture Commons, Archaeological Anthropology Commons, Environmental Studies Commons, Other American Studies Commons, Other Arts and Humanities Commons, Other History of Art, Architecture, and Archaeology Commons, and the United States History Commons

Tell us how this article helped you.

This Article is brought to you for free and open access by the Center for Regional Heritage Research at SFA ScholarWorks. It has been accepted for inclusion in Index of Texas Archaeology: Open Access Gray Literature from the Lone Star State by an authorized editor of SFA ScholarWorks. For more information, please contact cdsscholarworks@sfasu.edu. 
Documentation of Ancestral Caddo Ceramic Vessels from the Harold Williams Site (41CP10), Camp County, Texas

\section{Creative Commons License}

\section{(c) (1) \&}

This work is licensed under a Creative Commons Attribution-NonCommercial 4.0 International License 


\title{
Documentation of Ancestral Caddo Ceramic Vessels from the Harold Williams Site (41CP10), Camp County, Texas
}

\author{
Timothy K. Perttula
}

\section{Introduction}

The Harold Williams site (41CP10) is a large ancestral Caddo community cemetery (Perttula and Nelson 1998:Table 22; Turner and Smith 2003) on Dry Creek in the Big Cypress Creek basin in Camp County, Texas (Figure 1). Caddo burials and associated ceramic vessel funerary offerings have been discovered and dug at the Harold Williams site since the 1940s, and in 1967 the Texas Archeological Society (TAS) held their annual field school at the site.

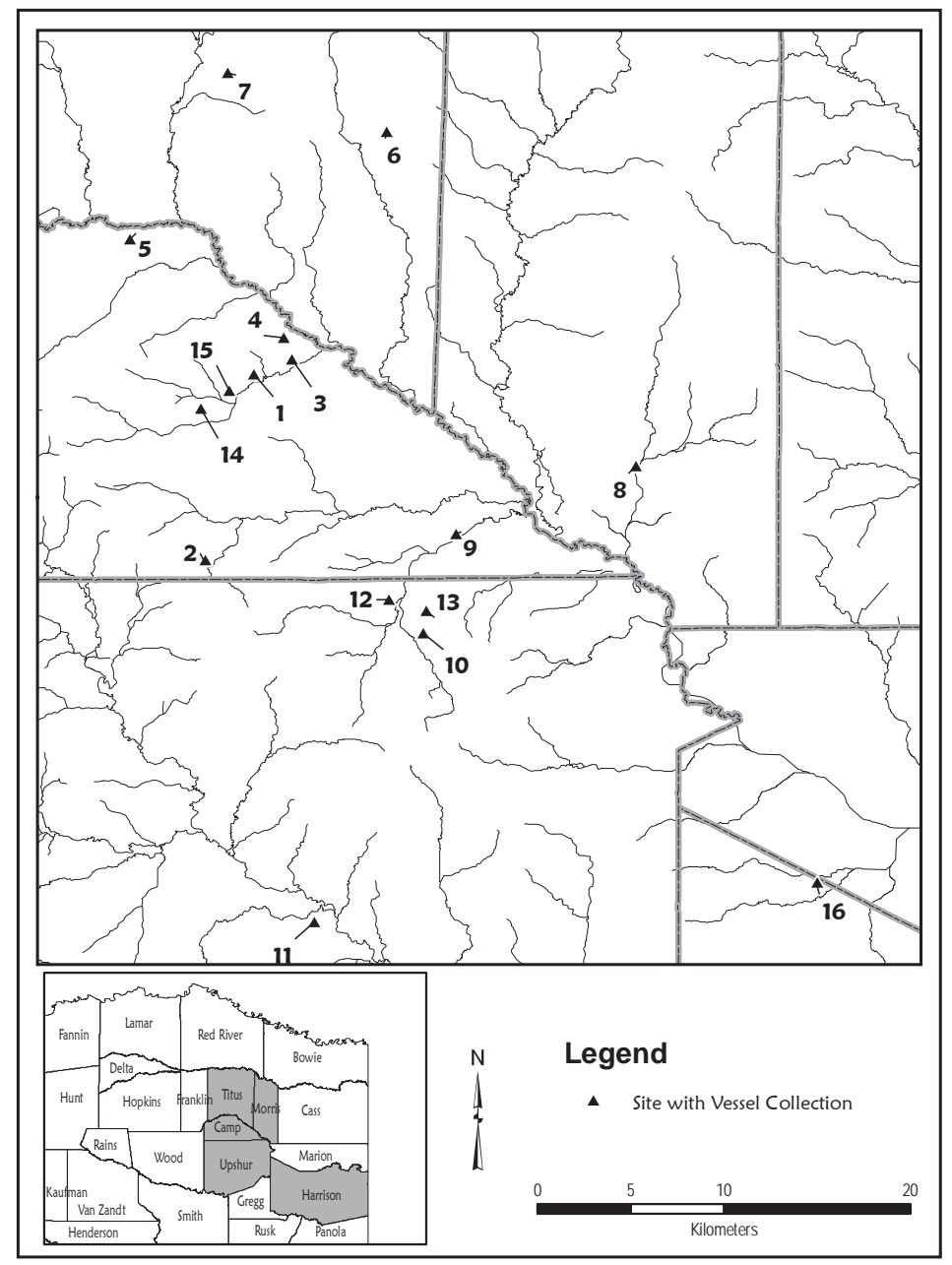

Figure 1. Important Caddo sites with documented vessel collections in the Big Cypress Creek basin in East Texas, including the Tuck Carpenter site: 1, Tuck Carpenter; 2, Johns; 3, Harold Williams; 4, Guest; 5 , Horton; 6, Alex Justiss; 7, Keith; 8, Lone Star Lake; 9, Rumsey; 10, Keeling; 11, Moughon; 12, Graydon Adkins \#1; 13, Graydon Adkins \#2; 14, Lineburger;15, Pug Wilson; and 16, Patton. 
During the course of the 1967 TAS excavations in Area A and B, several burial features were encountered and excavated, and these had associated ceramic vessels and other grave goods. These vessels were illustrated and cursorily described by Turner and Smith (2003:11, 39 and Figures 11m, x, 13a-d, 26a-j), and they were from Late Caddo period Titus phase graves. Recently two boxes of TAS Field School materials from the Harold Williams site were re-examined at the Texas Archeological Research Laboratory, and a number of whole and partial Caddo ceramic vessels from the TAS work were re-discovered. I took the opportunity to examine and document these vessels in detail, and the results of these analyses are presented in this article.

\section{Ceramic Vessels}

SITE NAME OR SITE NUMBER: Harold Williams (41CP10)

VESSEL NO.: Area A, Pot B

VESSEL FORM: Bottle with a short neck (see Turner and Smith 2003:Figure 13d)

NON-PLASTICS AND PASTE: grog

RIM AND LIP FORM: Direct rim and rounded lip

CORE COLOR: $\mathrm{G}$ (fired in a reducing environment and cooled in the open air)

INTERIOR SURFACE COLOR: dark grayish-brown

EXTERIOR SURFACE COLOR: yellowish-brown

WALL THICKNESS (IN MM): rim, $4.2 \mathrm{~mm}$; body, $5.6 \mathrm{~mm}$

INTERIOR SURFACE TREATMENT: none

EXTERIOR SURFACE TREATMENT:

burnished

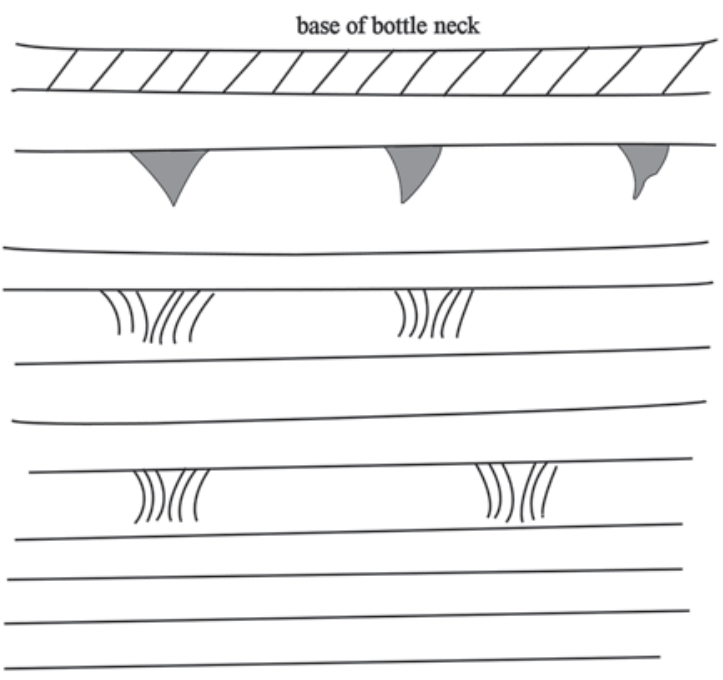

DECORATION (INCLUDING MOTIF AND ELEMENTS WHEN APPARENT): The vessel body has a series of horizontal engraved elements, beginning with a zone of diagonal engraved lines at the top of the bottle body bottom and just below the plain neck (Figure

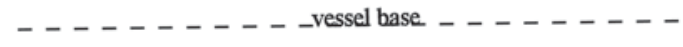

Figure 2. Decorative elements on engraved bottle (Area A, Pot B) from the Harold Williams site. 
2). Below that is a horizontal engraved line with 11 downward-pointing excised pendant triangles, followed by a single horizontal engraved line, then two horizontal engraved lines with eight sets of curvilinear bracket elements between them. This is followed by another single horizontal engraved line, then two more horizontal engraved lines with seven curvilinear engraved brackets between them (Figure 2). Below those lines are three more horizontal engraved lines, the lowermost of which ends $1.9 \mathrm{~cm}$ above the vessel base.

PIGMENT USE AND LOCATION ON VESSEL: none

TYPE AND VARIETY (IF KNOWN): Unidentified fine ware

SITE NAME OR SITE NUMBER: Harold Williams (41CP10)

VESSEL NO.: Area A, Vessel C, X41CP1 B539

VESSEL FORM: Jar (see Turner and Smith 2003:Figure 13d)

NON-PLASTICS AND PASTE: grog and hematite

RIM AND LIP FORM: Everted rim and rounded lip

CORE COLOR: $\mathrm{F}$ (fired in a reducing environment and cooled in the open air)

INTERIOR SURFACE COLOR: dark yellowish-brown; fire clouds on the rim, body, and base

EXTERIOR SURFACE COLOR: dark yellowish-brown; fire clouds on the rim, body, and base

WALL THICKNESS (IN MM): rim, $8.4 \mathrm{~mm}$

INTERIOR SURFACE TREATMENT: smoothed

EXTERIOR SURFACE TREATMENT: burnished

HEIGHT (IN CM): 10.2

ORIFICE DIAMETER (IN CM): 11.4

DIAMETER AT BOTTOM OF RIM OR NECK (IN CM): 11.0

BASE DIAMETER (IN CM) AND SHAPE OF BASE: $8.3 \mathrm{~cm}$, circular and flat

ESTIMATED VOLUME (IN LITERS): 0.7

DECORATION (INCLUDING MOTIF AND ELEMENTS WHEN APPARENT): Plain

PIGMENT USE AND LOCATION ON VESSEL: none

TYPE AND VARIETY (IF KNOWN): Unidentified plain ware 
SITE NAME OR SITE NUMBER: Harold Williams (41CP10)

VESSEL NO.: Area A, Pot G (south of F Burial)

VESSEL FORM: Jar

NON-PLASTICS AND PASTE: grog and hematite

RIM AND LIP FORM: Everted rim and rounded lip

CORE COLOR: H (fired in a reducing environment and cooled in the open air)

INTERIOR SURFACE COLOR: yellowish-brown

EXTERIOR SURFACE COLOR: dark grayish-brown

WALL THICKNESS (IN MM): rim, $7.0 \mathrm{~mm}$; body, $7.5 \mathrm{~mm}$; base, $10.3 \mathrm{~mm}$

INTERIOR SURFACE TREATMENT: smoothed

EXTERIOR SURFACE TREATMENT: none

HEIGHT (IN CM): 12.5

ORIFICE DIAMETER (IN CM): 8.0

DIAMETER AT BOTTOM OF RIM OR NECK (IN CM): 7.9

BASE DIAMETER (IN CM) AND SHAPE OF

BASE: $5.4 \mathrm{~cm}$, circular and flat

ESTIMATED VOLUME (IN LITERS): 0.6

DECORATION (INCLUDING MOTIF AND ELEMENTS WHEN APPARENT): On the rim, there is a single horizontal row of tool punctations below the lip, and sets of vertical pinched rows (probably four around the vessel). Between the vertical pinched rows are panels filled with opposed diagonal brushed marks (Figure 3). The vessel body has sets (probably four around the vessel) of two vertical pinched rows that extend to the vessel base. Between the vertical pinched rows are panels with vertical brushed marks. The vessel lip is also notched.

PIGMENT USE AND LOCATION ON VESSEL: none

TYPE AND VARIETY (IF KNOWN):

Unidentified utility ware

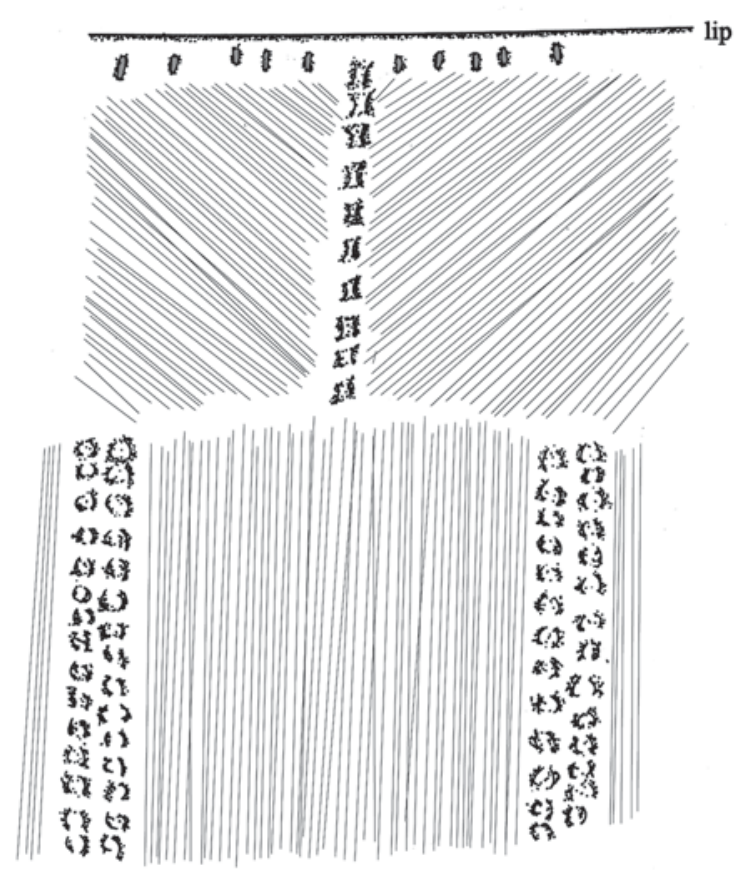

Figure 3. Decorative elements on BrushedPinched-Punctated jar (Area A, Pot G) from the Harold Williams site. 
SITE NAME OR SITE NUMBER: Harold Williams (41CP10)

VESSEL NO.: Area B, Trench 2, previously potted vessel (probably Grave A, Turner and Smith 2003:33); X41CP1, B860

VESSEL FORM: Bottle

NON-PLASTICS AND PASTE: grog

RIM AND LIP FORM: N/A

CORE COLOR: B (fired and cooled in a reducing environment)

INTERIOR SURFACE COLOR: dark grayish-brown

EXTERIOR SURFACE COLOR: very dark grayish-brown, possible slip

WALL THICKNESS (IN MM): neck, $4.2 \mathrm{~mm}$; body, $3.5 \mathrm{~mm}$

INTERIOR SURFACE TREATMENT: none

EXTERIOR SURFACE TREATMENT: burnished

HEIGHT (IN CM): N/A

ORIFICE DIAMETER (IN CM): N/A

DIAMETER AT BOTTOM OF RIM OR NECK (IN CM): N/A

BASE DIAMETER (IN CM) AND SHAPE OF BASE: N/A

ESTIMATED VOLUME (IN LITERS): N/A

DECORATION (INCLUDING MOTIF AND

ELEMENTS WHEN APPARENT): There are three horizontal engraved lines on the vessel neck, and the engraved body has an interlocking and hooked arm scroll motif where the scrolls meet at an excised circle element (Figure 4). There are excised bands above where the hooked arms of the scroll pass each other. The scrolls begin at the apex of upper and lower pendant triangle elements that have two hatched corners.

PIGMENT USE AND LOCATION ON VESSEL: red pigment in the engraved lines

TYPE AND VARIETY (IF KNOWN): Wilder Engraved, var. Wilder (see Perttula et al.

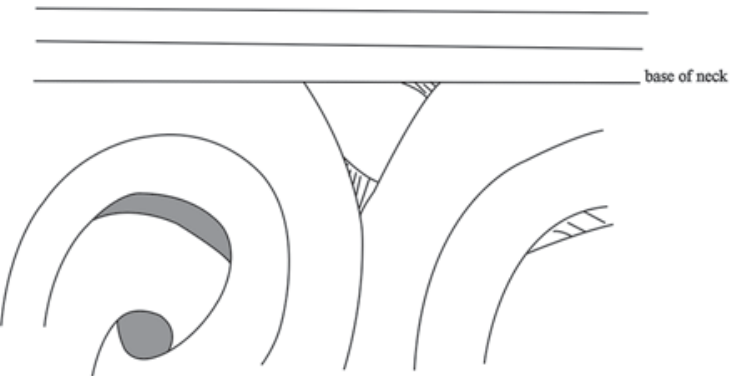

Figure 4. Decorative elements on Wilder Engraved, var. Wilder bottle (Area B, Trench 2) from the Harold Williams site. 
SITE NAME OR SITE NUMBER: Harold Williams (41CP10)

VESSEL NO.: Area B, Pot 14 (see Turner and Smith 2003:Figure 11m)

VESSEL FORM: carinated bowl

NON-PLASTICS AND PASTE: grog and sandy paste

RIM AND LIP FORM: Direct rim and a rounded, exterior folded lip

CORE COLOR: G (fired in a reducing environment and cooled in the open air)

INTERIOR SURFACE COLOR: dark grayish-brown

EXTERIOR SURFACE COLOR: brown

WALL THICKNESS (IN MM): rim, $6.2 \mathrm{~mm}$; body, $7.9 \mathrm{~mm}$

INTERIOR SURFACE TREATMENT: burnished

EXTERIOR SURFACE TREATMENT: burnished

HEIGHT (IN CM): 6.2

ORIFICE DIAMETER (IN CM): 15.0

DIAMETER AT BOTTOM OF RIM OR NECK (IN CM): 14.8

BASE DIAMETER (IN CM) AND SHAPE OF BASE: N/A

ESTIMATED VOLUME (IN LITERS): 0.6

DECORATION (INCLUDING MOTIF AND ELEMENTS WHEN APPARENT): the rim panel has two alternating sets of central elements partially connected by either horizontal or slanting scroll lines: circles with a smaller excised inner circle and diamonds with an inner diamond and negative oval (Figure 5). The upper and lower horizontal engraved lines of the panel have excised pendant triangles as well as curvilinear excised triangular elements.

PIGMENT USE AND LOCATION ON VESSEL: none

TYPE AND VARIETY (IF KNOWN): Ripley Engraved, var. McKinney (Perttula et al. 2012:Figure 5a; Fields et al. 2014:Table 8.6)

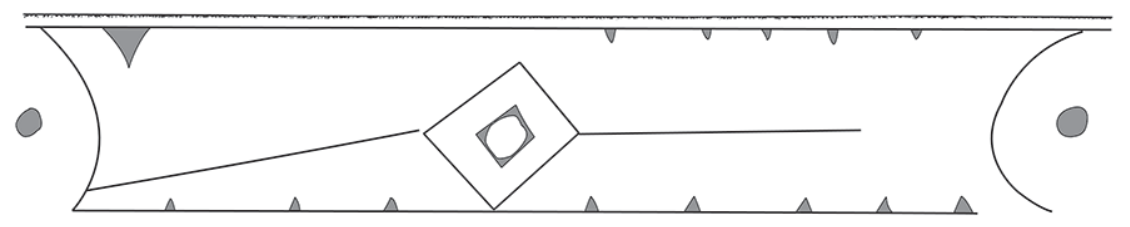

Figure 5. Decorative elements on Ripley Engraved, var. McKinney carinated bowl (Area B, Pot 14) from the Harold Williams site. 
SITE NAME OR SITE NUMBER: Harold Williams (41CP10)

VESSEL NO.: Pot A, Trench B, X41CP1 B896

VESSEL FORM: Jar, with the rim of the vessel missing (see Turner and Smith 2003:Figure 26f)

NON-PLASTICS AND PASTE: grog

RIM AND LIP FORM: N/A

CORE COLOR: $\mathrm{G}$ (fired in a reducing environment and cooled in the open air)

INTERIOR SURFACE COLOR: dark grayish-brown

EXTERIOR SURFACE COLOR: yellowish-brown

WALL THICKNESS (IN MM): body, 6.3-8.1 mm

INTERIOR SURFACE TREATMENT: none

EXTERIOR SURFACE TREATMENT: smoothed on the body

HEIGHT (IN CM): 10.8+

ORIFICE DIAMETER (IN CM): 18.9

DIAMETER AT BOTTOM OF RIM OR NECK (IN CM): N/A

BASE DIAMETER (IN CM) AND SHAPE OF BASE: $8.3 \mathrm{~cm}$, circular and flat

ESTIMATED VOLUME (IN LITERS): $1.2+$

DECORATION (INCLUDING MOTIF AND ELEMENTS WHEN APPARENT): Plain body

PIGMENT USE AND LOCATION ON VESSEL: none

TYPE AND VARIETY (IF KNOWN): Unidentified ware

SITE NAME OR SITE NUMBER: Harold Williams (41CP10)

VESSEL NO.: Pot D, Trench B, X41CP1 B886

VESSEL FORM: Jar (see Turner and Smith 2003:Figure 26h)

NON-PLASTICS AND PASTE: grog

RIM AND LIP FORM: Everted rim and rounded lip

CORE COLOR: $\mathrm{G}$ (fired in a reducing environment and cooled in the open air)

INTERIOR SURFACE COLOR: very dark grayish-brown 
EXTERIOR SURFACE COLOR: dark yellowish-brown; fire clouds on the body; organic remains on the rim and body

WALL THICKNESS (IN MM): rim, $5.5 \mathrm{~mm}$

INTERIOR SURFACE TREATMENT: smoothed

EXTERIOR SURFACE TREATMENT: none

HEIGHT (IN CM): 15.2

ORIFICE DIAMETER (IN CM): 12.1

DIAMETER AT BOTTOM OF RIM OR NECK (IN CM): 11.9

BASE DIAMETER (IN CM) AND SHAPE OF BASE: $6.4 \mathrm{~cm}$, circular and flat

ESTIMATED VOLUME (IN LITERS): 1.1

DECORATION (INCLUDING MOTIF AND ELEMENTS WHEN APPARENT): The rim has two rows of tool punctations, one beneath the lip and the other at the rim-body juncture. Between the punctated rows is a continuous series of diagonal incised lines pitched from left to right (Figure 6).

PIGMENT USE AND LOCATION ON VESSEL: none

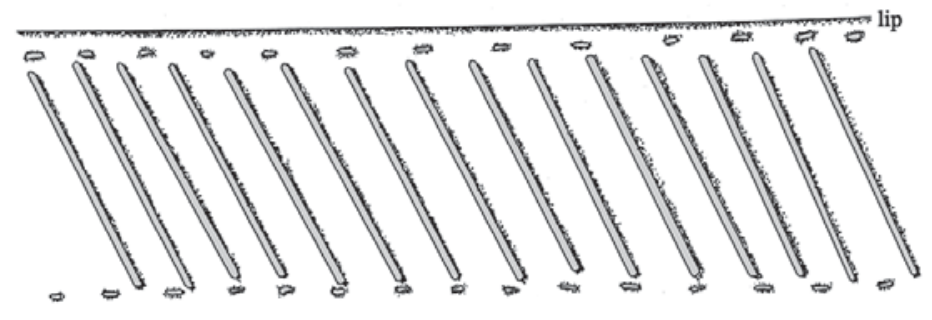

Figure 6. Decorative elements on Maydelle Incised jar (Pot D, Trench B) from the Harold Williams site.

TYPE AND VARIETY (IF KNOWN): Maydelle Incised (see Suhm and Jelks 1962:Plate 52)

SITE NAME OR SITE NUMBER: Harold Williams (41CP10)

VESSEL NO.: Pot E, Trench B, Pot Cluster 3, X41CP1 B891

VESSEL FORM: Bowl (see Turner and Smith 2003:Figure 26i)

NON-PLASTICS AND PASTE: grog

RIM AND LIP FORM: Direct rim and rounded lip

CORE COLOR: $\mathrm{F}$ (fired in a reducing environment and cooled in the open air)

INTERIOR SURFACE COLOR: dark yellowish-brown; fire clouds on the rim, body, and base

EXTERIOR SURFACE COLOR: light grayish-brown; fire clouds on the rim, body, and base

WALL THICKNESS (IN MM): rim, $4.9 \mathrm{~mm}$ 
INTERIOR SURFACE TREATMENT: smoothed

EXTERIOR SURFACE TREATMENT: burnished

HEIGHT (IN CM): 7.6

ORIFICE DIAMETER (IN CM): 14.8

DIAMETER AT BOTTOM OF RIM OR NECK (IN CM):

N/A

BASE DIAMETER (IN CM) AND SHAPE OF

BASE: $5.1 \mathrm{~cm}$, circular and flat

ESTIMATED VOLUME (IN LITERS): 0.5

DECORATION (INCLUDING MOTIF AND

ELEMENTS WHEN APPARENT): The vessel

has seven sets of engraved alternate nested

triangles (Figure 7). Each nested triangle has

curvilinear hatched corners and small central

circle elements.

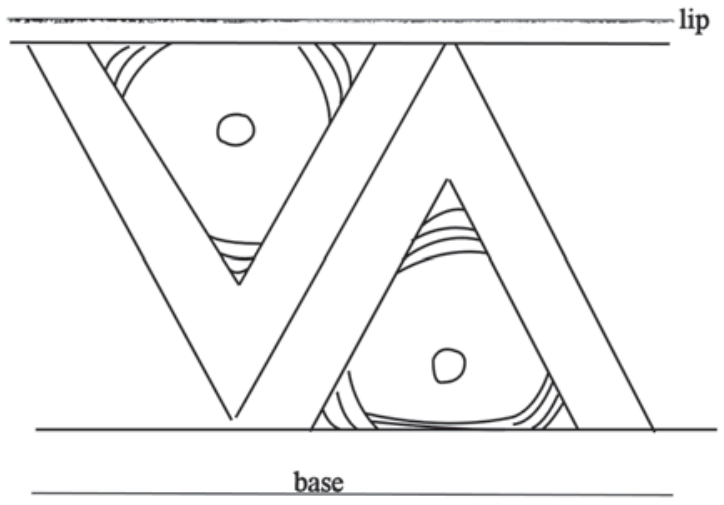

Figure 7. Decorative elements on Ripley Engraved, var. Williams bowl (Pot E, Trench B) from the Harold Williams site. none

TYPE AND VARIETY (IF KNOWN): Ripley

Engraved, var. Williams (see Perttula et al. 2012:Figure 5h; Fields et al. 2014:Table 8.6)

SITE NAME OR SITE NUMBER: Harold Williams (41CP10)

VESSEL NO.: Pot G, Trench D, X41CP1 A885

VESSEL FORM: Carinated bowl (see Turner and Smith 2033:Figure 26j)

NON-PLASTICS AND PASTE: grog

RIM AND LIP FORM: Direct rim and rounded, exterior folded, lip

CORE COLOR: G (fired in a reducing environment and cooled in the open air)

INTERIOR SURFACE COLOR: dark grayish-brown

EXTERIOR SURFACE COLOR: brown

WALL THICKNESS (IN MM): rim, $5.5 \mathrm{~mm}$

INTERIOR SURFACE TREATMENT: burnished

EXTERIOR SURFACE TREATMENT: burnished 
HEIGHT (IN CM): 2.8

ORIFICE DIAMETER (IN CM): 10.0

DIAMETER AT BOTTOM OF RIM OR NECK (IN CM): 9.8

BASE DIAMETER (IN CM) AND SHAPE OF BASE: $4.9 \mathrm{~cm}$, circular and flat

ESTIMATED VOLUME (IN LITERS): 0.2

DECORATION (INCLUDING MOTIF AND ELEMENTS WHEN APPARENT):

The rim panel has four repeating sets of engraved continuous scroll motifs (Figure 8). The scroll motif is comprised of sets of three closely-spaced vertical engraved lines and a connecting slanting scroll line. The upper scroll fill zone has a triangle element with small excised areas, while the lower scroll fill zone has a large triangle element with an inner negative oval defined by bracket-shaped excised areas (Figure 8). There is also a single horizontal engraved line at the

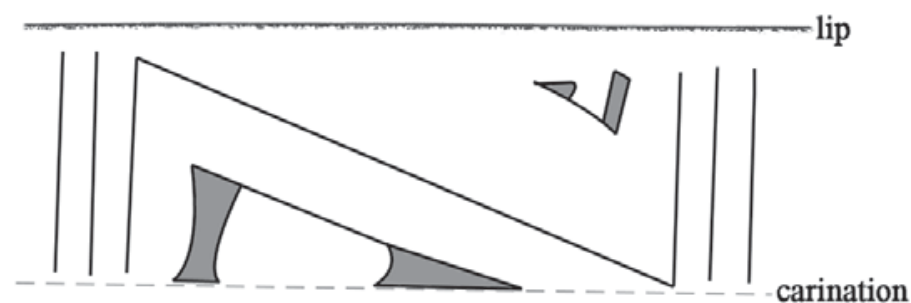

Figure 8. Decorative elements on Ripley Engraved, var. Carpenter carinated bowl (Pot G, Trench D) from the Harold Williams site. interior vessel surface carination.

PIGMENT USE AND LOCATION ON VESSEL: white pigment rubbed in the engraved lines

TYPE AND VARIETY (IF KNOWN): Ripley Engraved, var. Carpenter (see Perttula et al. 2012:Figure 5f; Fields et al. 2014:Table 8.6)

SITE NAME OR SITE NUMBER: Harold Williams (41CP10)

VESSEL NO.: H, X41CP1 B890

VESSEL FORM: Jar with rim peaks (see Turner and Smith 2003:Figure 26d)

NON-PLASTICS AND PASTE: grog and sandy paste

RIM AND LIP FORM: Everted rim and rounded, exterior folded, lip

CORE COLOR: F (fired in a reducing environment and cooled in the open air)

INTERIOR SURFACE COLOR: dark reddish-brown

EXTERIOR SURFACE COLOR: dark yellowish-brown; fire clouds on the rim and body

WALL THICKNESS (IN MM): rim, $6.5 \mathrm{~mm}$

INTERIOR SURFACE TREATMENT: burnished at the rim and smoothed on the body

EXTERIOR SURFACE TREATMENT: smoothed on the base 
HEIGHT (IN CM): $14.4 ; 14.9 \mathrm{~cm}$ at the rim peaks

ORIFICE DIAMETER (IN CM): 14.7

DIAMETER AT BOTTOM OF RIM OR NECK (IN

CM): 14.4

BASE DIAMETER (IN CM) AND SHAPE OF

BASE: $8.9 \mathrm{~cm}$, circular and flat

ESTIMATED VOLUME (IN LITERS): 1.3

DECORATION (INCLUDING MOTIF AND

ELEMENTS WHEN APPARENT): The rim panel has a continuous series of short vertical incised lines that are divided by four sets of two vertical appliqued nodes; the appliqued nodes are centered under the rim peaks (Figure 9). On the vessel body are eight sets of vertical appliqued fillets that extend to the vessel base; these are also centered under the rim peaks. Between these vertical appliqued fillets are 16 sets of vertical incised panels filled with vertical rows of tool punctations (Figure 9).

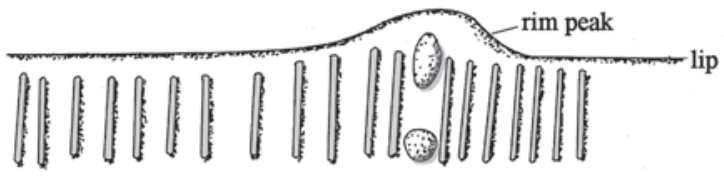

PIGMENT USE AND LOCATION ON VESSEL:

none

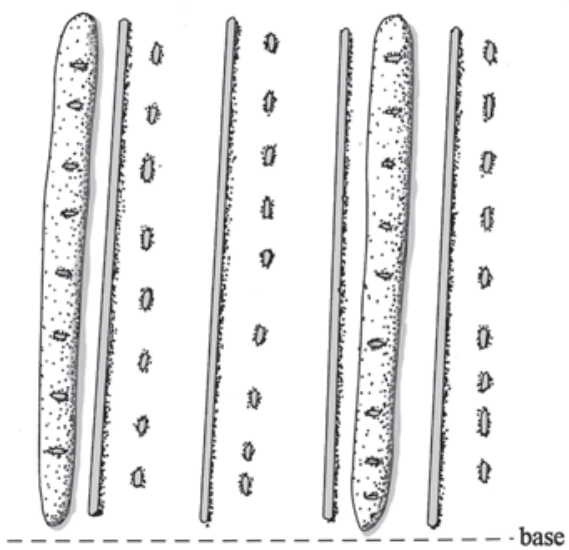

Figure 9. Decorative elements on Pease Brushed-Incised jar (Vessel H) from the Harold Williams site.

TYPE AND VARIETY (IF KNOWN): Pease Brushed-Incised (see Suhm and Jelks 1962:Plate 60)

SITE NAME OR SITE NUMBER: Harold Williams (41CP10)

VESSEL NO.: Pot I, Pot Cluster 1, X41CP1 B886

VESSEL FORM: Jar (see Turner and Smith 2003:Figure 26e)

NON-PLASTICS AND PASTE: grog and bone

RIM AND LIP FORM: Everted rim and rounded, exterior folded, lip

CORE COLOR: $\mathrm{H}$ (fired in a reducing environment and cooled in the open air)

INTERIOR SURFACE COLOR: dark yellowish-brown; fire clouds on the rim; organic remains on the rim and body

EXTERIOR SURFACE COLOR: dark grayish-brown; fire clouds on the body and base

WALL THICKNESS (IN MM): rim, $4.9 \mathrm{~mm}$

INTERIOR SURFACE TREATMENT: burnished on the rim, otherwise smoothed

EXTERIOR SURFACE TREATMENT: burnished on the lower body and smoothed on the base 
HEIGHT (IN CM): 11.8

ORIFICE DIAMETER (IN CM): 12.7

DIAMETER AT BOTTOM OF RIM OR NECK (IN CM): 12.3

BASE DIAMETER (IN CM) AND SHAPE OF BASE: $5.7 \mathrm{~cm}$, circular and flat

ESTIMATED VOLUME (IN LITERS): 0.9

DECORATION (INCLUDING MOTIF AND ELEMENTS WHEN APPARENT): The rim has at least eight horizontal rows of tool punctations, as well as four sets of three vertical appliqued nodes. The vessel body has tool punctated rows over the entire body, except for the lowest $2.0 \mathrm{~cm}$ of the vessel, which is plain.

PIGMENT USE AND LOCATION ON VESSEL: none

TYPE AND VARIETY (IF KNOWN): cf. Mockingbird Punctated (see Perttula et al. 1998)

SITE NAME OR SITE NUMBER: Harold Williams (41CP10)

VESSEL NO.: Vessel J, Pot Cluster 1, X41CP1 B889

VESSEL FORM: Jar (see Turner and Smith 2003:Figure 26a)

NON-PLASTICS AND PASTE: grog

RIM AND LIP FORM: Everted rim and rounded lip

CORE COLOR: B (fired and cooled in a reducing environment)

INTERIOR SURFACE COLOR: very dark grayish-brown

EXTERIOR SURFACE COLOR: very dark grayish-brown

WALL THICKNESS (IN MM): rim, $6.3 \mathrm{~mm}$

INTERIOR SURFACE TREATMENT: smoothed

EXTERIOR SURFACE TREATMENT: smoothed on the body

HEIGHT (IN CM): 8.7

ORIFICE DIAMETER (IN CM): 8.2

DIAMETER AT BOTTOM OF RIM OR NECK (IN CM): 7.5

BASE DIAMETER (IN CM) AND SHAPE OF BASE: $5.9 \mathrm{~cm}$, circular and flat

ESTIMATED VOLUME (IN LITERS): 0.4 
DECORATION (INCLUDING MOTIF AND ELEMENTS WHEN APPARENT): The rim panel is defined by single upper and lower horizontal incised lines. Between these horizontal lines are upper and lower sets of embedded incised triangle elements and sets of diagonal opposed incised lines (Figure 10).

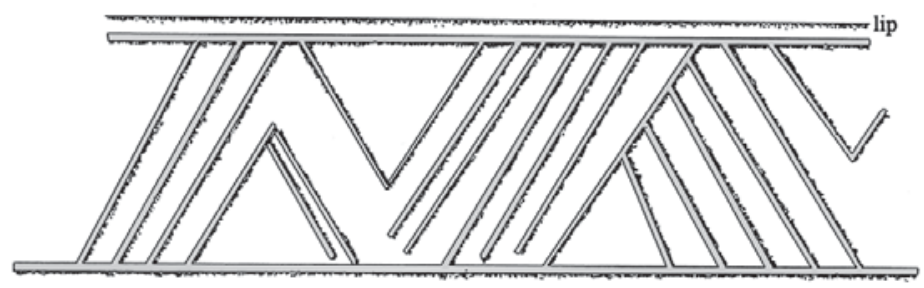

Figure 10. Decorative elements on Maydelle Incised jar (Vessel J, Pot Cluster 1) from the Harold Williams site.

PIGMENT USE AND LOCATION ON

VESSEL: none

TYPE AND VARIETY (IF KNOWN): Maydelle Incised

SITE NAME OR SITE NUMBER: Harold Williams (41CP10)

VESSEL NO.: Pot B, Trench 8, X41CP1 B893

VESSEL FORM: Jar with four rim peaks (see Turner and Smith 2003:Figure 26g)

NON-PLASTICS AND PASTE: grog

RIM AND LIP FORM: Direct rim and rounded, exterior folded, lip

CORE COLOR: $\mathrm{F}$ (fired in a reducing environment and cooled in the open air)

INTERIOR SURFACE COLOR: yellowish-brown; fire clouds on the rim, body, and base

EXTERIOR SURFACE COLOR: dark yellowish-brown; fire clouds on the rim, body, and base; organic remains on the rim and body

WALL THICKNESS (IN MM): rim, $5.0 \mathrm{~mm}$; body, $5.4 \mathrm{~mm}$

INTERIOR SURFACE TREATMENT: smoothed

EXTERIOR SURFACE TREATMENT: smoothed to burnished on the body

HEIGHT (IN CM): $10.0 \mathrm{~cm} ; 10.2 \mathrm{~cm}$ at the rim peaks

ORIFICE DIAMETER (IN CM): 10.8

DIAMETER AT BOTTOM OF RIM OR NECK (IN CM): 10.7

BASE DIAMETER (IN CM) AND SHAPE OF BASE: $5.1 \mathrm{~cm}$, circular and flat

ESTIMATED VOLUME (IN LITERS): 0.6

DECORATION (INCLUDING MOTIF AND ELEMENTS WHEN APPARENT): The rim has three horizontal rows of tool punctations, with four short vertical appliqued fillets beneath the first and second 
punctated row (Figure 11). The vertical appliqued fillets on the rim are set below each of the rim peaks. Four vertical appliqued fillets are on the vessel body, also beneath the rim peaks. These appliqued fillets extend to within $2.9 \mathrm{~cm}$ of the vessel base.

PIGMENT USE AND LOCATION ON VESSEL: none

TYPE AND VARIETY (IF KNOWN): cf. Mockingbird Punctated

SITE NAME OR SITE NUMBER: Harold Williams (41CP10)

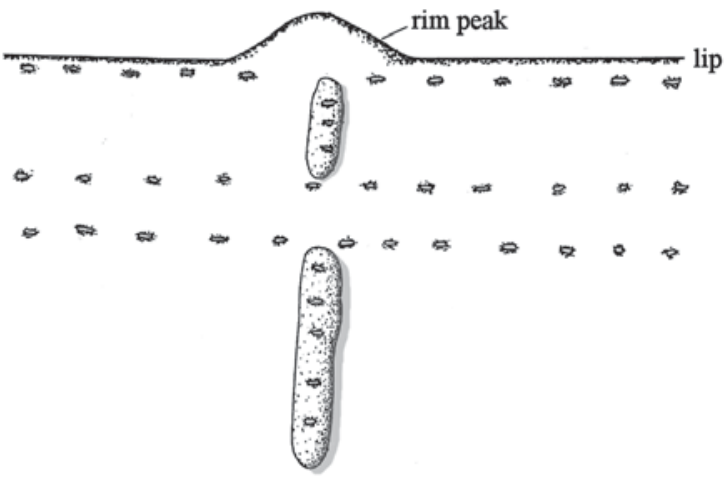

Figure 11. Decorative elements on cf. Mockingbird Punctated jar (Pot B, Trench 8) from the Harold Williams site.

VESSEL NO.: Pot K, Trench 9, X41CP1 B887

VESSEL FORM: Jar (see Turner and Smith 2003:Figure 26b)

NON-PLASTICS AND PASTE: grog and bone

RIM AND LIP FORM: Direct rim and rounded lip

CORE COLOR: $\mathrm{F}$ (fired in a reducing environment and cooled in the open air)

INTERIOR SURFACE COLOR: reddish-brown; fire clouds on the rim

EXTERIOR SURFACE COLOR: reddish-brown; fire clouds on the rim, body, and base

WALL THICKNESS (IN MM): rim, $4.8 \mathrm{~mm}$

INTERIOR SURFACE TREATMENT: smoothed on the rim

EXTERIOR SURFACE TREATMENT: smoothed on the body

HEIGHT (IN CM): 9.5

ORIFICE DIAMETER (IN CM): 10.9

DIAMETER AT BOTTOM OF RIM OR NECK (IN CM): 10.9

BASE DIAMETER (IN CM) AND SHAPE OF

BASE: $6.4 \mathrm{~cm}$, circular and flat

ESTIMATED VOLUME (IN LITERS): 0.6

DECORATION (INCLUDING MOTIF AND ELEMENTS WHEN APPARENT): The rim has a series of diagonal opposed incised lines and incised triangles filled with tool punctations.

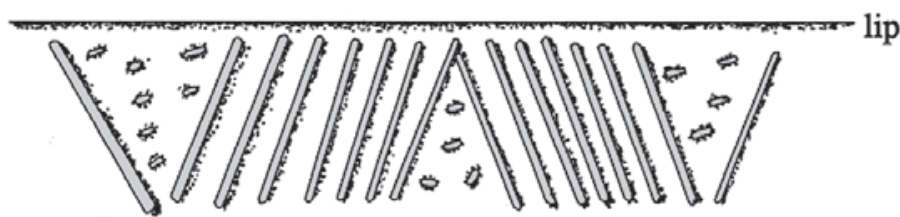

Figure 12. Decorative elements on Maydelle Incised jar (Pot $\mathrm{K}$, Trench 9) from the Harold Williams site. 
PIGMENT USE AND LOCATION ON VESSEL: none

TYPE AND VARIETY (IF KNOWN): Maydelle Incised

SITE NAME OR SITE NUMBER: Harold Williams (41CP10)

VESSEL NO.: Pot M, Trench 9, X41CP1 B887

VESSEL FORM: Jar (see Turner and Smith 2003:Figure 26c)

NON-PLASTICS AND PASTE: grog

RIM AND LIP FORM: Direct rim and rounded, exterior folded, lip

CORE COLOR: B (fired and cooled in a reducing environment)

INTERIOR SURFACE COLOR: very dark grayish-brown

EXTERIOR SURFACE COLOR: dark grayish-brown; fire clouds on the rim, body, and base; organic remains on the body

WALL THICKNESS (IN MM): rim, 6.4 mm; body, $7.1 \mathrm{~mm}$

INTERIOR SURFACE TREATMENT: smoothed

EXTERIOR SURFACE TREATMENT: smoothed on the lower body

HEIGHT (IN CM): 14.3

ORIFICE DIAMETER (IN CM): 14.0

DIAMETER AT BOTTOM OF RIM OR NECK (IN CM): 13.9

BASE DIAMETER (IN CM) AND SHAPE OF

BASE: $6.4 \mathrm{~cm}$, circular and flat

ESTIMATED VOLUME (IN LITERS): 1.2

DECORATION (INCLUDING MOTIF AND

ELEMENTS WHEN APPARENT): The rim has a

continuous series of diagonal incised lines pitched from right to left (Figure 13). The vessel body has a continuous series of vertical incised lines that extend to within $3.7 \mathrm{~cm}$ of the vessel base.

PIGMENT USE AND LOCATION ON VESSEL: none

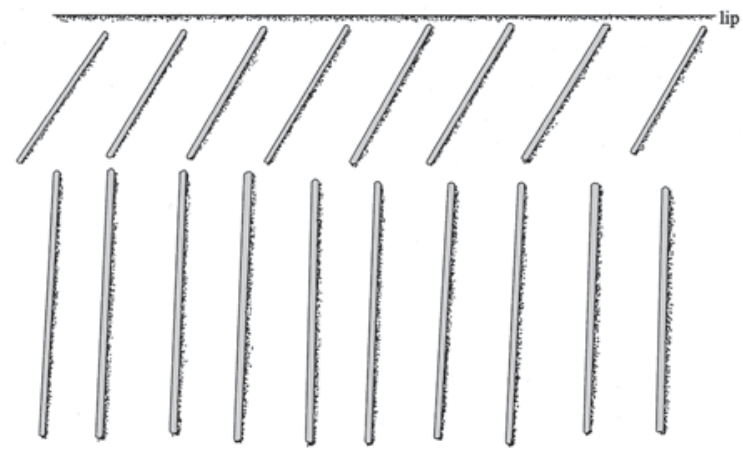

Figure 13. Decorative elements on Maydelle Incised jar (Pot M, Trench 9) from the Harold Williams site (41CP10).

TYPE AND VARIETY (IF KNOWN): Maydelle Incised 


\section{Summary and Conclusions}

The Harold Williams site (41CP10) is a large ancestral Caddo habitation site and cemetery on Dry Creek, a northward-flowing tributary to Big Cypress Creek in the East Texas Pineywoods. Although the scene of much digging for burial features and associated grave goods since the 1940s, the first concerted intensive study of the site and its cultural features took place during the 1967 Texas Archeological Society annual field school (Turner and Smith 2003). During the excavations in two adjoining parts of the site (Areas A and B, see Turner and Smith 2003:Figure 2), several Caddo burial features were encountered and excavated, and these features had associated funerary offerings, particularly ceramic vessels. These vessels, in the collections of the Texas Archeological Research Laboratory (TARL), are documented in detail in this article.

In Area A at the Harold Williams site, three Caddo ceramic vessels were documented from a single Middle Caddo period (ca. A.D. 1200-1400) burial feature (Turner and Smith 2003:11. These vessels include an engraved bottle, a plain jar, and a brushed-pinched-punctated-lip notched jar that resembles Pease Brushed-Incised; three plain jars and bowls from this feature were not present at TARL to be documented. The documented vessels were tempered with grog or grog and hematite. The best evidence for the Middle Caddo period use of Area A is a Nacogdoches Engraved bottle with an engraved rattlesnake motif (see Turner and Smith 2003:Figure 12b, d-e; see also Hart and Perttula 2010; Walters 2006), and several platform pipes (Turner and Smith 2003:12 and Figure 10b-d).

The 3-4 burial features in Area B may be child burials dating to the latter part of the Late Caddo period Titus phase. Turner and Smith $(2003: 54,65)$ estimate that these burials, probably in or near a house compound, likely date from ca. A.D. 1550 to the early A.D. 1600s. There are 12 ceramic vessels from these burials in the TARL collection, all tempered with grog. Two (16.7 percent) of the vessels are also tempered with burned bone, and two others were made from a local sandy clay.

One jar from Area B is of an unidentified ware because the rim is missing, seven other vessels are utility ware jars, and four are fine ware bottles, bowls, and carinated bowls. The utility ware jars include four of the Maydelle Incised type, another two are cf. Mockingbird Punctated vessels, and the last is a Pease Brushed-Incised jar. The fine ware vessels from Area B include a Wilder Engraved, var. Wilder bottle, a Ripley Engraved, var. Williams bowl, and two Ripley Engraved carinated bowls: var. Carpenter and var. McKinney.

\section{Acknowledgments}

Thanks to Marybeth Tomka and Lauren Bussiere of the Texas Archeological Research Laboratory at The University of Texas at Austin for access to the vessel collections from the Harold Williams site. Lance Trask prepared the figures for this article.

\section{References Cited}

Fields, R. C., V. L. Hatfield, D. Burden, E. F. Gadus, M. C. Wilder, and K. W. Kibler

2014 Testing and Data Recovery Excavations at 11 Native American Archeological Sites along the U.S. Highway 271 Mount Pleasant Relief Route, Titus County, Texas. 2 Vols. Reports of Investigations No. 168. Prewitt and Associates, Inc., Austin.

Hart, J. P. and T. K. Perttula

2010 The Washington Square Mound Site and a Southeastern Ceremonial Complex Style Zone among the Caddo of Northeastern Texas. Midcontinental Journal of Archaeology 35(2):199-228. 
Perttula, T. K. and B. Nelson

1998 Titus Phase Mortuary Practices in the Northeast Texas Pineywoods and Post Oak Savanna. In Analysis of the Titus Phase Mortuary Assemblage at the Mockingbird or "Kahbakayammaahin" Site (41TT550), by T. K. Perttula, M. Tate, H. Neff, J. W. Cogswell, M. D. Glascock, E. Skokan, S. Mulholland, R. Rogers, and B. Nelson, pp. 328-401. Document No. 970849. Espey, Huston \& Associates, Inc., Austin.

Perttula, T. K., B. Nelson, and M. Walters

2012 Caddo Archaeology at the Henry Spencer Site (41UR315) in the Little Cypress Creek Basin of East Texas. Special Publication No. 20. Friends of Northeast Texas Archaeology, Pittsburg and Austin.

Perttula, T. K., M. Tate, H. Neff, J. W. Cogswell, M. D. Glascock, E. Skokan, S. Mulholland, R. Rogers, and B. Nelson

1998 Analysis of the Titus Phase Mortuary Assemblage at the Mockingbird Site Kahbakayammaahin” (41TT550). Document No. 970849. Espey, Huston \& Associates, Inc., Austin.

Suhm, D. A. and E. B. Jelks (editors)

1962 Handbook of Texas Archeology: Type Descriptions. Special Publication No. 1, Texas Archeological Society, and Bulletin No. 4, Texas Memorial Museum, Austin.

Turner, R. L. and J. E. Smith II

2003 The Harold Williams Site (41CP10) and the Texas Archeological Society Field School of 1967. Bulletin of the Texas Archeological Society 73:1-68.

Walters, $\mathrm{M}$.

2006 The Lake Clear (41SM243) Site and Crotalus horridus atricaudatus. Caddoan Archeology Journal 15:5-41. 